Covered in: ERIH PLUS, HeinOnline, CEEOL, Index Copernicus, CrossRef, CrossCheck, J-GATE, Google Scholar, Ideas RePeC, Econpapers, Socionet, KVK, WorldCat.

2018, Volume 6, Issue 1, pages: 1-12 | doi: https://doi.org/10.18662/lumenlaw/01

\section{New Institutions for the 21 st Century Global Order of Peace: The Mediator for Global Peace}

\section{Mădălina Virginia ANTONESCU1}

${ }^{1}$ Ph.D., scientific researcher, Romanian Diplomatic Institute, vam55ro@yahoo.com

\begin{abstract}
The "Peace" concept has plenty of new meanings, marked by the influence of the complex 21 st century society of states. Due to this fact, our paper explores the hypothesis of creating an innovative global institution, such as the Mediator for Global Peace that we are proposing here, as a functional method of harmonizing different perceptions and visions among the civilizations and states of the international and global disputes, in the depths of 21 st century society. This (the MGP) is conceived as a new institution designed to act outside of the old UN-centred20th century-specific institutional umbrella, in a complex global order (marked also by actions specific to non-state actors), even in new fields (such as defence of the terrestrial ecosystems and of the rights of the planet Earth, endangered by state and non-state actors activities).
\end{abstract}

Keywords: Mediator for Global Peace, UN, global institutions, global order of peace, Agenda 2030.

How to cite: Antonescu, M. (2018). New Institutions for the 21st Century Global Order of Peace: The Mediator for Global Peace. Logos Universality Mentality Education Novelty: Law, 6(1), 1-12. https://doi.org/10.18662/lumenlaw/01 



\section{The Mediator for Global Peace - a New Global Institution in the Dynamic Order of the $2^{1 \text { st }}$ Century}

Our proposal for the present paper is the institution of the Global Mediator of Peace, considering the extended meanings of the concept of "peace", as presented in major documents, for what we call the structure of "a global order of peace". Some of these documents, let's call them proto-global, although they are signed and assumed by sovereign states, under the aegis of the UN, are paramount for the basis of a new global architecture of peace, specific to the $21^{\text {st }}$ century, in a post-UN order, maintaining their roots in the current role of the $\mathrm{UN}^{1}$ (General Assembly, Resolution adopted by the General Assembly on 25 September 2015).

In our opinion, the Mediator for Global Peace can be such a postUN institution (if we consider the real importance of maintaining a sustainable environment of peace and international security, in order to fulfil the objectives connected to sustainable development, taken upon in the 2030 Agenda). At the moment of the 2030 Agenda, the UN was an unreformed institution, dating back to 1945 and belonging to a system of international organization, which no longer finds its place in the reality of the international world (Devin, 2005). .

Thus, starting from the more generic senses of the concept of "peace" for the $21^{\text {st }}$ century, in a dynamic political order, we note a battle between the strong neo-Westphalian trend (pre-eminence of the nationstate, an absolutization of the concept of "sovereignty", going as far as isolationism) and a globalist tendency (pre-eminence of the global institutions, absolutization of the concept of "multi-tier governance", the concept of "shared competences" and the sectorial movements of regional integration) ${ }^{3}$ (Gonidec, 1981). However, the $21^{\text {st }}$ century world is not that easily divided. Both movements must take into consideration the evolution

\footnotetext{
1 We consider that Agenda 2030 is such a proto-global document. See General Assembly, Resolution adopted by the General Assembly on September 25 $5^{\text {th }} 2015$, A/RES/70/1, distrib. on October 21st2015, Transforming Our World: The 2030 Agenda for Sustainable Development, www.un.org/ga/search

${ }^{2}$ According to certain authors, the order based on the UN system must not be considered "a final and fixed stage of multilateralism". On the contrary, it is to be considered a "specific moment of interstate cooperation", which questioned and can be changed (for example, through a strong unilateralist policy, such as the one assumed by the United States, after September 11 th 2001$)$.

${ }^{3}$ Certain authors consider that the EU to be a supranational decision-making organization, based on the transfer of state competences, as well as on a true decision-making power, unlike the cooperation organizations.
} 
New Institutions for the 21st Century Global Order of Peace: The Mediator for ... Mădălina Virginia ANTONESCU

of the non-state actors, the massive and uncontrolled migratory flows, which move suddenly on entire continents, the pollution and climate changes, the dangers caused by the progress of industrial technologies and pollution, the situation of the unique and fragile terrestrial ecosystems, impoverishment and financial crises with impact on countries or entire regions, depletion of drinking water resources and food crisis, migrations from the rural area to the metropolises, urban crime and urban terrorism. In addition, it is important to consider forms of asymmetrical threats, regional, transnational or urban instability, all being major threats to this political order of the $21^{\text {st }}$ century, with an equally negative impact on the Northern industrialized and rich countries, with lower and aging population, and on the poor South, in full demographic bloom (Owen, 2016, pp.40-41, 28-29), (Bedjaoui, 1978, pp. 26-35). Under these circumstances, peace becomes a complex concept which is impossible to manage solely in the terms of the Westphalian order and exclusively by the state. The limitations of the UN Council of Security are obvious, when handling unconventional, asymmetrical threats. Many of these threats are not even legally regulated at international level, they are not banned or perceived as threats to peace (massive and sudden migratory flows across countries, meteorological wars, international terrorism, urban terrorism etc.)

Under these circumstances, global institutions with special tasks at global level are required to manage issues and threats to peace, which are also defined in key-documents (acknowledged by the states) as global threats.

In our opinion, Westphalian instruments (multilateralism, bilateralism) cannot adequately handle global challenges, which require the approval of all the states, in a unanimity that needs to be renewed and leads to blockages in the initiatives to regulate an issue seen as global, in due time and effectively.

Global issues are of interest for the mankind as such, beside the major options of mankind, fate of the planet, balance among ecosystems and global peace.

In our opinion, the very existence of these global issues, as well as the high risk of other issues becoming global during the future decades (chronic impoverishment of the developing countries, demographic issues of the South, intensive and polluting industrialization in the South, in emerging countries, global warming, greenhouse gases, the risk of losing biodiversity, the lessening of drinking water resources, massive deforestation and intensive chemical agriculture, extended desertification etc.) (Bedjaoui, 1978, pp. 30-33) require the creation of an entire global security architecture (Evans \& Newnham, 2001). We understand the "global security" phrase in an extended sense, also including the following concepts: "food security", "human 
security", "water security", and "environmental security". Such concepts add new dimensions of legal protection at universal and even global level (assumed by the states in The Agenda 2030 document) to the concept of "security", adjusting it to the complex realities of the world, in the first half of the $21^{\text {st }}$ century.

In this context of global challenges, we consider that the creation of a global institution such the GMP (Global Mediator of Peace) is based on the necessity for a correct perception of the fact that traditional regional and international threats start to turn into challenges at global level (given the restructuring of the world according to certain highly dangerous conflict patterns, which gain on the legally ordered world of the states, based on the UN principles). Such a restructuring of the world, in the first half of the $21^{\text {st }}$ century, is based on the inter-civilizational and religious conflicts. These types of conflicts are global and even if they start at local or regional level, given the nature of civilizations and religions involved, they have global effects (possible on account of the intercivilizational or inter-religion conflicts, including alliances among civilizations and religions against other civilizations and religions) (Griffiths, 2005). Since we cannot consider civilizations and religions to be subjects of international public law, such as the sovereign states, currently there are no international conventions for these types of conflicts (transnational by excellence), conventions adopted and assumed by the states, or other legal instruments which, according to the contemporary order of international law, acknowledge the religions and civilizations as distinct global actors. Therefore, we note that the fundamental principles defined in the UN Charter cannot apply to a world dominated by such types of global restructuring and conflicts. The fundamental principles of law in the UN Charter consider a world structured and ordered around nation-states, while the notion of "international dispute" exclusively and fundamentally involves the state, not other actors. The limitation of the UN Charter from this viewpoint (of the new types of conflicts and actors) becomes obvious; the principles of the Westphalian world are no longer able to hold control over a dynamic and complex, multi-layered world, such as the world in the second half of the $21^{\text {st }}$ century.

For this reason, we consider that the world in the second half of the $21^{\text {st }}$ century can be controlled in order to avoid chaos or stages of postmodern barbarism (post-Westphalian crisis, anarchic globalism), by setting up a series of global legal regulations and global institutions, which are able to respond to global issues, prevent them and solve them at a higher and imperative level of the current international law.

In our opinion, the competences of the MGP should satisfy the need for defending what is insufficiently protected or even unprotected from the international 
New Institutions for the 21st Century Global Order of Peace: The Mediator for ... Mădălina Virginia ANTONESCU

legal standpoint: rights of nature, rights of the planet Earth (as a distinct subject of global environmental law). Such rights must be defended by their own representatives, at all levels, facing the danger that certain states exercise absolute forms of certain rights, with a direct and irremediable impact on the environment, biodiversity, the right of the future generations to a peaceful international environment, stable, safe, rich in resources, rights such as: the right to development, the right to technical and technological advance, the right to an unlimited exploitation of nature and its resources (derived from an absolute interpretation of the "permanent and unlimited sovereignty of each people over its own resources of the soil and subsoil"), plus the need to provide a global response to issues such as the following: trans-border pollution, actions committed by multinational companies interested in conquering new markets, obligation of the states to refrain from using force or the threat of force, obligation of the states to find a peaceful solution for the disputes among them, obligation of the states to cooperate peaceful among each other and with all the states.

In our opinion, the MGP (The Mediator for Global Peace) should have the following competences:

- In the sense of the current international law (based on the principle of sovereignty and equality of rights among all the states), all the UN member states should assign competences to the new global institution (MGP), for the latter to have universally acknowledged and legitimate competences (validly based on the free will approval of all the UN member states).

- To set up the MGP, the UN member states should unanimously sign and adopt a treaty for the creation of this global institution (or a set of global institutions, including the MGP), with clearly stated attributions and standalone financing, distinct from the UN or its member states.

- In the context of a post-sovereign or anarchic global order, in which the UN principles of equal rights among all the states are either denounced or they lose their value, given the fundamental restructuring of the entire UN order, in contexts such as a world conflict or a non-violent form of reorganizing the world, when faced with world calamities or global challenges exceeding the individual competences of the states and the UN competences, the creation of global institutions would no longer require the approval of all the states. This situation is possible because, in such a scenario, in a post-sovereign or anarchic world, the legitimacy no longer belongs to the representatives of the former order (denounced or in process of fundamental restructuring). Instead, it is assumed by the representatives of the new order (a small group of challenger-states). If the group of challenger-states assumes the restructuring of the international order and, in 
the context of questioning or abandoning de facto the UN institutions, mechanisms and principles (as being Westphalian by nature), it sets the basis of a global order (using a set of global principles and a convention assumed by this group of leader-states), and it is sufficient to stipulate the set of global institutions and their competences in this convention assumed by the challenger-states, in the context in which all the previous institutions and regulations have fallen (as the result of a world conflict, of a global threat or even by consent of all the UN member states to peacefully adopt a global order, which they can no longer manage adequately, individually or using the current UN mechanisms).

- The creation of the MGP global institution (and other global institutions) would therefore be the effect of a major restructuring process, covering the entire international world, of a transfer from the Westphalian principles to the global principles (with hierarchic authorities superior to the states, with the imperative tasks of penalizing the states, a post-sovereign world) (Held, McGrew; Golblatt, Perraton, 2004), (Fukuyama, 2004).

In this scenario, the global law will replace the current international law (Fukuyama, 2004, pp. 94-98.) and it will be based on the global institutions, as global main subjects of law, as well as on a low capacity of the states to participate as subject of global law in the elaboration of global law regulations (in this post-sovereign or anarchic order, the states become limited subjects of global law, in a manner similar today to the international organizations). In a global law, certain intergovernmental international organizations would be restructured and would become global organizations (primary and full subjects of global law), while other organizations would be set up as global from the very beginning (through global agreements among the groups of leader-states).

- In a post-sovereign and/or archaic order, the occurrence of the MGP and of other global institutions would be the result of the common will of a group of large actors, which openly assumed the role to restructure the existing order and to issue a new set of regulations and principles (global), to set up a new series of (global) institutions, in order to management a series of issues perceived by everyone as global and identified in the basic covenant as having this character and requiring a global response. We can discuss about a global order resulted either as an effect of the common will of the group of leaderstates, or as a global order created by a single state (dominant), in a postsovereign and post-Westphalian order ${ }^{4}$ (Smouts, Battistella, Vennesson,

\footnotetext{
${ }^{4}$ According to certain authors, globalization questions the Westphalian system, its principles and actors (the preeminent nation-states).
} 
2006). Therefore, in this scenario, the global institutions, principles and regulations should be the exclusive result of a single state's will and perception of the global order (hegemon of the new order).

The creation of the MGP can be regarded as the effect of the need to provide a fast and efficient response to global challenges with irremediable consequences for the fate of the planet and the human life: the need to acknowledge and protect the rights of the planet Earth, the rights of nature, which are endangered by the actions of the states and the non-state actors (especially multinational company) or by local, regional, international conflicts, as well as by technologies with the potential to destroy the very life on Earth.

\section{The Mediator for Global Peace, a New Institution in a World of "Global Gladiators"}

Alvin Toffler considers that the world of the future belongs only to "Global Gladiators". According to him, "we are clearly heading for chaos, unless new international laws are written and new agencies are created or unless the essential global Gladiators, such as transnational corporations, religions and similar forces, are denied representation in new agencies" (Toffler, 1995, p. 459). Toffler avoids a clear definition of the "global gladiators", in the $21^{\text {st }}$ century global order. He only notes "the greatest change in global affairs, after the occurrence of the nation-state" which, in his opinion, is "the arrival of global gladiators" (Toffler, 1995, p. 453), regarded as "a group of seekers of power, which take the stage of the world and grab large chunks of the influence held only by the nations" (Toffler, 1995, p. 453). He considers that, for example, "religions will create their own sovereignties, higher than the state sovereignties, and will use them to claim control over knowledge, over the minds of the people" (on the premise that a non-state, transnational actor, such as a religious cult, could have rights above the rights of the simple nation-states) (Toffler, 1995, p. 454). Megacompanies (or non-national corporations) can be other non-state actors, "completely separated from the influence of any nation, which protects its customers, not its country" (Toffler,1995, p. 457).

It is a complex, dynamic, post-sovereign world, in which Toffler sees the UN as an organization with a limited and obsolete role ("a commercial association of state-nations") (Toffler, 1995, p. 459), which would have to make room to the non-state actors with global influence (NGOs, transnational companies, religious cults etc. which should have voting rights as members of a new, post-Westphalian order). 
According to Toffler, the global architecture of power can be picture both on the basis of a vertical model of power organization and on the basis of a horizontal model of power organization. In the first scenario, the global institutions would be the expression of "an institutional model in full ascension", focused on a supranational control (Toffler, 1995, pp. 460-461).

Toffler considers that "we are witnessing a significant shift in power from the individual or grouped state-nations to the global gladiators....", which leads to "the next global revolution of the political forms" (Toffler, 1995, pp. 462-463).

However, in the current paper, we see the global institutions as expressions of the hierarchic model, which tends to refashion the anarchic structure of the world order during the first half of the $21^{\text {st }}$ century. In our opinion, the response to the proliferation and diversification of non-state actors would be adding a new supra-state level of power, which is able to control the movements of the non-state actors from a hierarchical-global level (superior to the inter-national level). In other words, we consider that only by transferring the decision-making power to a superior level is it possible to control the actions with global impact of the great non-state actors, not by creating new forms of cooperation among them (since they are not subjects of international law, currently, and therefore have no legal responsibility similar to that of the states, from the standpoint of the contemporary international law, whence the limitation of this right).

Thus, the MGP institution would be the expression of a superior hierarchical level of power, when compared to the state level, with the legitimate responsibility to regulate the entire world order and to avoid a state of anarchy or this order being questioned by non-state actors.

\section{The Mediator for Global Peace's competences}

Our opinion regarding the creation of a set of global competences for this new institution is the following:

- The Mediator for Global Peace should have competences in relation to all the states (a dimension adjusted to the global order, in which the international level is no longer the sole and ultimate decision-making level.

- The MGP should also have competences covering non-state actors (a dimension adjusted to the complex, non-state order).

Under these circumstances, based on a Global Covenant, initiated and assumed by the group of new states, which decide to restructure the entire global order - the rising powers (threatened by disorder, chaos, by the fact that the entire axiological and power basis of the existing order is challenged, by a world conflict, by global issues etc.), global institutions such as the MGP 
New Institutions for the 21st Century Global Order of Peace: The Mediator for ...

could make decisions at global level (seen as a superior, hierarchical level, with decision-making power superior to the power of the nation-states), in matters of global interest and impact, clearly stated in the Global Covenant and acknowledged by the group of states which initiates the new type of global order.

- Competences in the preservation of peace and global stability (MGP can decide to send global patrols of peace, global observers of peace)

- Competences related to the global protection of the environment (MGP can decide to penalize transnational companies for activities with serious impact on the terrestrial ecosystems, on the environment in a country or at transnational level)

- Global competences regarding the penalization of global polluters (states or non-state actors)

- Competences related to the monitoring of the peaceful use of technologies with a global destructive potential (annual update of the list of monitored countries, with such harmful technologies, and their obligations to observe their rules of use).

- Competences related to summoning the Global Council for the Preservation of Peace (when global issues or global disputes handled by the MGP require major global decisions regarding the fate of the planet and mankind, depending on the major negative dimension of the issue or the dispute), Council where the MGP holds a decision-making position (with the right to vote)

- Competences related to the protection of the rights held by the planet Earth (MGP can decide to dispatch observers for the rights of the planet Earth to intergovernmental institutions and the governments of the member-states)

- Competences related to solving global disputes

- Competences related to defining the concept of "global urban terrorism"

- Competences related to defining and solving conflicts with a terrorist component and global implications

- Competences related to the fair management of renewable resources of drinking water and the renewal of ecosystems- natural sources of healthy food for the peoples of the planet.

\section{Conclusions}

In the ever changing world of the early $21^{\text {st }}$ century, a world in which nation-states do not have the capacity to identify and solve the global issues of this world, in a coherent multilateral manner, according to a unique and generally accepted agenda, we consider that it is necessary to create a global institutional architecture, equipped with special competences at global level. 
The institution we propose in the present paper, i.e. the Mediator for Global Peace, corresponds to an architectural model of "great ascension", if we quote Toffler (Toffler, 1995, p. 460), or a vertical model of power organization in which, a new global level is added above the international level of the nation-states.

This global level of power ${ }^{5}$ (Simileanu, 2011, p. 39) a level necessary to identify, manage, monitor, solve certain issues, which are global in nature, impact and consequences or which occurred as a result of certain actions and decisions made by certain global actors, such a level can be an expression of the free and common will, of the transfer of sovereign competences from the UN member states to a higher level, a global level of power (the classic approach, already experimented by creating the $\mathrm{EU}$, compatible to the international law) (Antonescu, 2009), (Antonescu, 2007), or it can be the result of denouncing the entire UN order (as a Westphalian order, unable to solve global issues, specific to a world completely different from the world ordered based on the Westphalian principle, with the instruments of traditional multilateralism or bilateralism).

The $21^{\text {st }}$ century world can be a post-sovereign world, a postWestphalian world, which requires the management of global issues at a level which is above the inter-national level.

The Westphalian principle which entails the cooperation among all the sovereign states, with equal rights (Mazilu, 1998, p. 150), can either be the foundation for the new post-sovereign order (with a decision-making level above the current inter-national level, based on the structure of the European (supranational), or it will be denounced by a global actor/group of global rising actors, together with the entire current international order, given the fact that it is impossible to solve the global issues with the current mechanisms of inter-state cooperation.

We consider that such a scenario is dangerous, since it may result in an alternate world, one based on the anarchic principle of chaos and disorder $^{6}$ (Kaldor, 1999), where no one would handle the global issues,

\footnotetext{
5 Other authors warn about the fact that there already is a higher level, called "global governance", a product of globalization, not of the will of the nation-state; therefore, global governance fails to be controlled by the nation-state. Global governance would entail nonstate actors, such as universal or global institutions, multinational corporations, organizations issuing regulations regarding the world order and other actors with other transnational purposes and objectives. This type of global governance beyond the control of the state and which no longer entails it poses the risk of leading to "disintegration of the state power".

${ }^{6}$ Other authors also acknowledge the fact that the phrase "national security" has reached its limits and that "there is currently great uncertainty regarding the future governance configurations. A security void is in discussion", entailing "an institutional debate" about the optimal model of institutions with the required competences to counter this void. This
} 
New Institutions for the 21st Century Global Order of Peace: The Mediator for ... Mădălina Virginia ANTONESCU

endangering the fate of the planet and the right of future generations to a peaceful, stable environment, free from terror, misery and injustice.

The architecture of the global institutions with the role to secure a Westphalian world and to avoid its downfall, at the same time solving the global issues on a legitimate basis, acknowledged by the nation-states, and on the basis of a global body of regulations, would be an alternative to chaos and world disorder, in the context of a chronic inability of the states to respond to global challenges using the classic, multilateralist method.

\section{References}

Antonescu, M.V. (2007). Instituțiile Uniunii Europene în perioada post-Nisa. O perspectivă de drept constitutional. Iaşi: Lumen Publishing House.

Antonescu, M.V. (2009). Uniunea Europeană și organizația international. Iaşi: Lumen Publishing House.

Bedjaoui, M. (1978). Pour un nouvel ordre économique international. Nouveaux défis au droit international. Paris : UNESCO, PUF.

Devin, G. (2005). Le multilatéralisme à la croisée des chemins, in Bertrand Badie et alii, Qui a peur du XXIe siècle? Le nowveau système international, Paris: La Decouverte

Evans, G., Newnham, J. (2001). Dicționar de relații internationale, translated by Anca Irina Ionescu, Universal Dalsi Publishing House, Bucharest.

Fukuyama, F. (2004). Constructia statelor. Ordinea mondială în secolul XXI, translated by Mihnea Columbeanu. Prahova: Antet XX Press Publishing House.

General Assembly, Resolution adopted by the General Assembly on 25 September 2015, A/RES/70/1, distrib. 21 October 2015, Transforming Our World: The 2030 Agenda for Sustainable Development. Retrieved from: www.un.org/ga/search

Gonidec, P. F. \& Charvin, R. (1981).Relations internationales, Ed. Montchrestien, Paris.

Griffiths, M. (ed.). (2005). Encyclopedia of international relations and global politics. London: Routledge, NY.

ecuation to solve the security question in the new world must take into consideration the privatization of organized crime, the transnationalization of military forces, the occurrence of new wars that go beyond the traditional control and competences of the states. 
Held, D., McGrew, A., Golblatt, D., Perraton, J. (2004). Transformări globale. Politică, economie şi cultură. Translated by Ramona-Elena Lupaşcu, Adriana Ştraub, Mihaela Bordea, Alina-Maria Turcu. Iaşi: Polirom.

Kaldor, M. (1999). Răz̧boaie vechi şi noi. Violenţa organizată în epoca globală,translated by Mihnea Columbeanu. Prahova: Antet Publishing House.

Mazilu, Dumitru. (1998). Dreptul păcii. Bucureşti: TratatAll Beck Publishing House.

Owen, Weldon. (2016). Marele Atlas ilustrat al lumii, Vidraşcu şi fiii Publishing House, translated by Graal Soft, Bucharest, $3^{\text {rd }}$ edition revised: Ed. Litera.

Simileanu, V. (2011). Globalizarea spațiului Islamic. Bucharest: Top Form Publishing House.

Smouts, M.-C., Battistella, D. Vennesson, P. (2006).Dictionnaire des relations internationales, Dalloz, Paris.

Toffler, A. (1995). Powershift. Puterea in miscare, translated by Mihnea Columbeanu. Prahova: Ed. Antet. 